\title{
The parallel lives of Joseph Allen Galbraith (1818- 90) and Samuel Haughton (1821-97): religion, friendship, scholarship and politics in Victorian Ireland
}

\author{
Miguel DeArce* \\ SEO, Department of Genetics, Trinity College Dublin
}

[Accepted 15 November 2010. Published 14 October 2011.]

Abstract

Introduction
Joseph Allen Galbraith and Samuel Haughton were both Junior Fellows at Trinity College Dublin, who in the 1840 s became popular lecturers of mathematics-based subjects as well as successful textbook authors. In the 1880s they were still working together as Senior Fellows at Council meetings in the College. For more than 20 years they shared undergraduate teaching while pursuing distinct individual interests. Galbraith was absorbed in the management of church property at the time of the church's disestablishment, in the politics of the Irish Home Rule Party and, as bursar, in the modernisation of Trinity College's accountancy methods. Haughton, while not neglecting his chair of Geology, was for many years secretary to the Council of the Royal Zoological Society of Ireland, and registrar of the Medical School of the University of Dublin. This was during a time of great reforms in government and expanding budgetary allocations to health services. A close friendship joined the two scholars throughout their life, sealed by the marriage of one of Galbraith's daughters to one of Haughton's sons. Both men were profoundly religious without sentimentality. Their mutual support helped them to pursue lives of exacting service to their country, even if their cause made them unpopular among narrow-minded but influential members of their peers.

Joseph Allen Galbraith (1818-90) and Samuel Haughton (1821-97) are not entirely unknown. ${ }^{1}$ However, such accounts as exist are repetitive and

\footnotetext{
* Author's e-mail: mdearce@tcd.ie doi: 10.3318/PRIAC.2011.112.XX

1 For Galbraith see Desmond McCabe, 'Joseph Allen Galbraith', in James McGuire and James Quinn (eds), Dictionary of Irish biography (hereafter DIB) (Cambridge, 2009), Vol. 4, 524-6. For Haughton see Patrick N. Wyse Jackson, 'Samuel Haughton', in McGuire and Quinn (eds), DIB, Vol. 4, 5-6. There are no substantial printed references to Galbraith, although his name is briefly mentioned by some historians of the Home Rule movement. For Haughton's life sketches see A.C. O'Sullivan, 'Haughton man of science', in Sidney Lee (ed.), Oxford dictionary of national biography (hereafter DNB), (London, 1909) 22, Archive, 823-25; W.J.E. Jessop, 'Samuel Haughton, a Victorian
} 


\section{Parallel lives}

fragmentary, and fail, in my opinion, both to make use of the available archival sources $^{2}$ and to provide a proper picture of these two very full lives of service, that have the added interest of being joined by a wonderful, and lifelong, friendship. That they were friends is, as I hope to illustrate below, intrinsic to any understanding of the nature of their work.

\section{Family and early achievements}

Joseph Allen Galbraith (Fig. 1) was Samuel Haughton's senior by nearly four years, and early in their careers at Trinity College, Galbraith used this fact to pull rank over Haughton when they were involved in joint projects that entailed some 'risk'. By comparison, Haughton seems to have initiated his friend in the natural sciences and laboratory work, with relatively little success, as Galbraith only published four papers on natural history during his early career, before turning his attention to politics and church administration.

Joseph Galbraith was the son of Richard Galbraith, of Scottish stock, and Rebecca Allen. Richard was a Dublin merchant and respected member of the Presbyterian church St Mary's Abbey. He died before Joseph's graduation, having lost most of his wealth. ${ }^{3}$ Galbraith entered Trinity College as a pensioner on 3 November 1834, graduating with a BA in 1839, and was made a Junior Fellow in 1844, showing an exceptional talent for the application

polymath', Hermathena 116 (1973), 5-26, and T.D. Spearman, 'Samuel Haughton (1821-1897)', in Lawrence Goldman (ed.), DNB, online edn (Oxford, 2004), available at: www.oxforddnb.com/view/article/12616?docPos $=8$ (last accessed 18 November 2010). For aspects of Haughton's anti-Darwinism, see Richard England, 'Natural selection before the Origin: public reactions of some naturalists to the Darwin-Wallace papers (Thomas Boyd, Arthur Hussey, and Henry Baker Tristram)', Journal of the History of Biology 30 (1997), 267-90; Peter J. Bowler, 'Charles Darwin and his Dublin critics: Samuel Haughton and William Henry Harvey', Proceedings of the Royal Irish Academy 109C (2009), 409-20, and Norman D. MacMillan, The Rev. Samuel Haughton, a man of great erudition and a determined opponent of the theory of evolution (Carlow, 1979). Galbraith and Haughton were frequently mentioned by name in Irish printed periodicals of their time, and their obituaries appeared nationwide and beyond (see below).

2 The archival material referenced here is mostly in the manuscripts section of Trinity College Library, and is henceforth referred to as TCD-JAG-MS and TCD-SH-MS for Joseph Allen Galbraith and Samuel Haughton respectively, followed by a numerical reference. Galbraith's material includes his diaries (1848-90), which do not cover every year in that interval (TCD-JAG-MS 3824-55). Haughton's work as governor of Sir Patrick Dunn's Hospital is minuted in the records of this hospital, now found in the archives of the Royal College of Physicians, Kildare Street, Dublin, where the original of his last will and testament can also be found. Other materials include the published work of both authors, and contemporary Irish newspapers (mostly online). No other cache of Haughton papers has been found so far.

3 Daily Express, 21 October 1890 (TCD-JAG-MS 3856/4/13). 


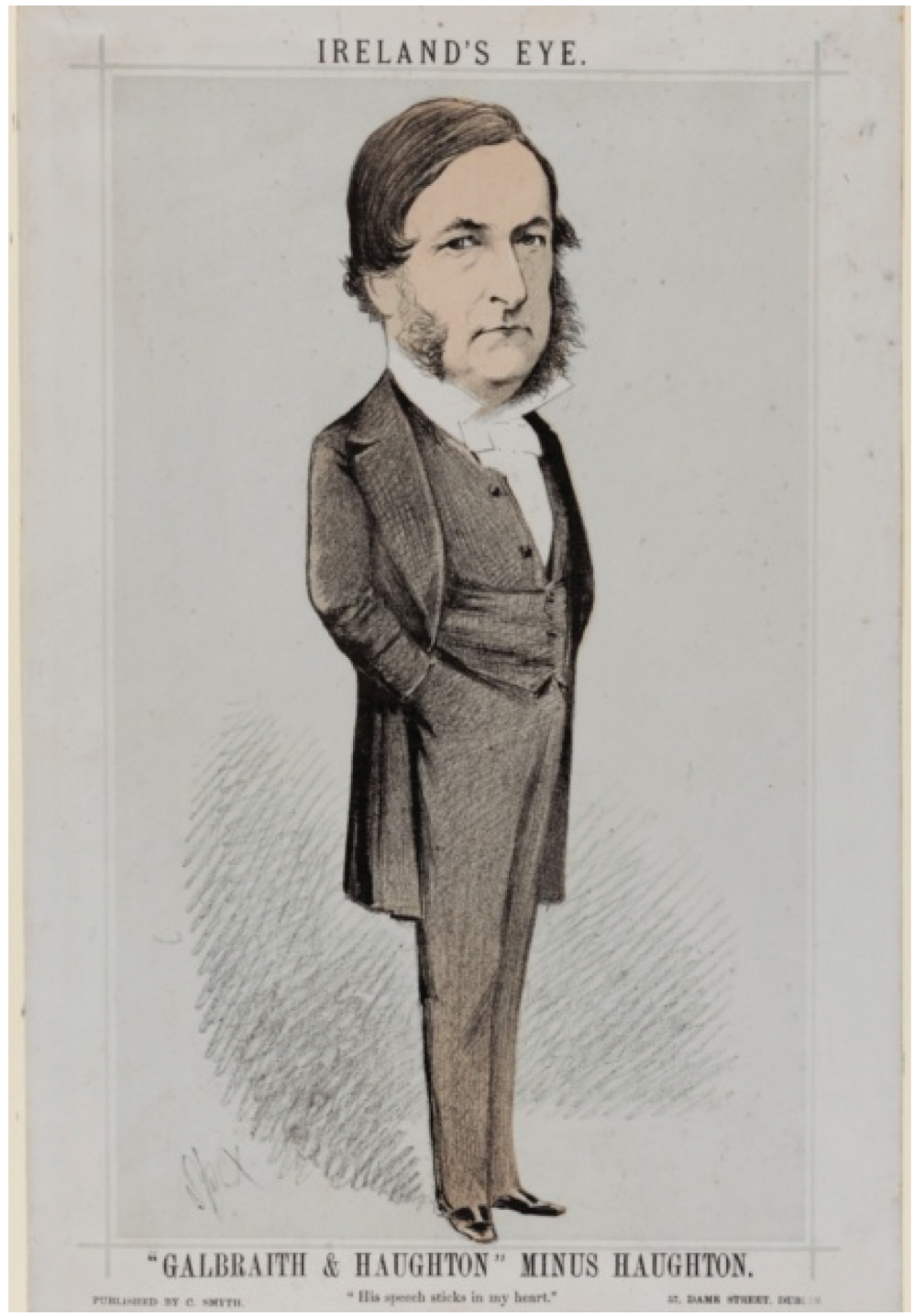

FIG. 1-'Galbraith and Haughton minus Haughton' as shown in Ireland's Eye, 10 October 1874, 74.

of mathematics to a wide range of everyday problems. ${ }^{4}$ He was admitted to holy orders in the established church in 1846, by Bishop Ludlow Tonson (later Baron Rivendale) of Killaloe and Kilfenora, ${ }^{5}$ but in later life he boasted of being a

\footnotetext{
${ }^{4}$ Some family details of Joseph Allen Galbraith can be found in James Blennerhasett, Leslie's biographical index, Church of Ireland clergy 614.2 405. This is a mixed medium document (typed with handwritten additions) that can be seen at the Library of the Church Representative Body in Churchtown, Dublin. Some of these are repeated in Pall Mall Review 23 (October 1890), which can be found In TCD-JAG-MS 3856/5, and a multitude of other obituaries therein.

5 The certificate is in TCD-JAG-MS 3856/4/1.
} 
good Presbyterian. Joseph married Hannah Maria, daughter of Rev. John Bredon (or Bredin) of Cavan, on 16 July 1850, and they had three sons and four daughters. ${ }^{6}$ He joined the Council of the Dublin Statistical Society in 1853, and in the same year he read an able paper on the advantages of a decimal system of currency. ${ }^{7}$ He became Erasmus Smith Professor of Natural Philosophy in 1854, holding the chair for 20 years. $^{8}$ He was a very popular lecturer, often gathering groups of students at his summer home in Greystones, Co. Wicklow, for Sunday dinner and afternoon discussions, ${ }^{9}$ accompanied by his inseparable and learned friend Rev. Haughton. His wife Hannah died in 1867, and his older daughter took over the running of the household.

Samuel Haughton (Fig. 2) was born in Carlow to Sarah Hancock (1787-1861) of Lurgan, and Samuel Haughton (1787-1877), a merchant of Burrin House, Co. Carlow. ${ }^{10}$ Sarah and Samuel were both Quakers who had

6 TCD-JAG-MS 3825 (entry for 1850). The entries related to the marriage are full of reverence and tenderness, but are also succinct. The couple married in the Collegiate Church of St Nicholas in Galway, and Hannah's sister Eugenia married Dr Charles Cheyne at the same time and place. Additional family details can be seen in Mount St Jerome cemetery in Rathgar, Dublin. Three children are mentioned on the gravestone as having died before their father. The local reference for the grave, which is a double plot surrounded by double kerbs and with a large limestone Celtic cross, is C-108-940, and it is very close to Sir William Wilde's grave. Hannah Maria, Galbraith's wife, who died on 7 July 1867, aged 45, is also buried there. All reports of Galbraith's funeral speak of three daughters as the chief mourners, without naming them, and two sons who were absent, one in India and one in Mauritius. Samuel Haughton is also mentioned as one of the chief mourners.

7 Joseph A. Galbraith, On decimal currency: Report of the Dublin Statistical Society seventh session (Dublin, 1853), 5.

8 Kerry Sentinel, 12 November 1890 (TCD-JAG-MS.3856/4/). According to the college calendar for 1874, which describes the conditions of the bequest in the case of Junior Fellows, the annual salary was $£ 700$. Given future events, this could hardly be more ironic. Galbraith, who became a champion of Home Rule, benefited early in his career from a bequest from Erasmus Smith (1611-91), a notorious proselytiser. 'He was a Cromwellian profiteer and land speculator who, in the period 1667-1670, deemed it prudent to create an endowment for schools for the cynical purpose of warding off a parliamentary inquiry into the rest of his estates, amounting to some 30,000 acres in some ten counties. The schools originally set up were three grammar schools in Drogheda, Galway and Tipperary. The provisions of the endowment stated that surplus revenues were to be applied to setting up schools to benefit the tenants on the Smith estates. But in the event the surplus which did accrue was diverted for the benefit of Trinity (in 1724, 1762 and 1774), and to set up 'English schools' with an overtly proselytising purpose.' (From the entry to the Armagh Diocesan Registry Archive, Erasmus Smith Endowment Archive, 39, Public Record Office of Northern Ireland (PRONI), available at: www.proni.gov.uk/introduction_armagh_diocesan_registry_ archive.pdf (25 May 2011).

9 One such party is described in the Kerry Sentinel, 12 November 1890 (TCD-JAG-MS 3856/4).

10 There appears to be some confusion in the Frances Clarke and James Quinn entry on James Haughton in the DIB, with regard to Samuel Haughton's (FRS) parents. 


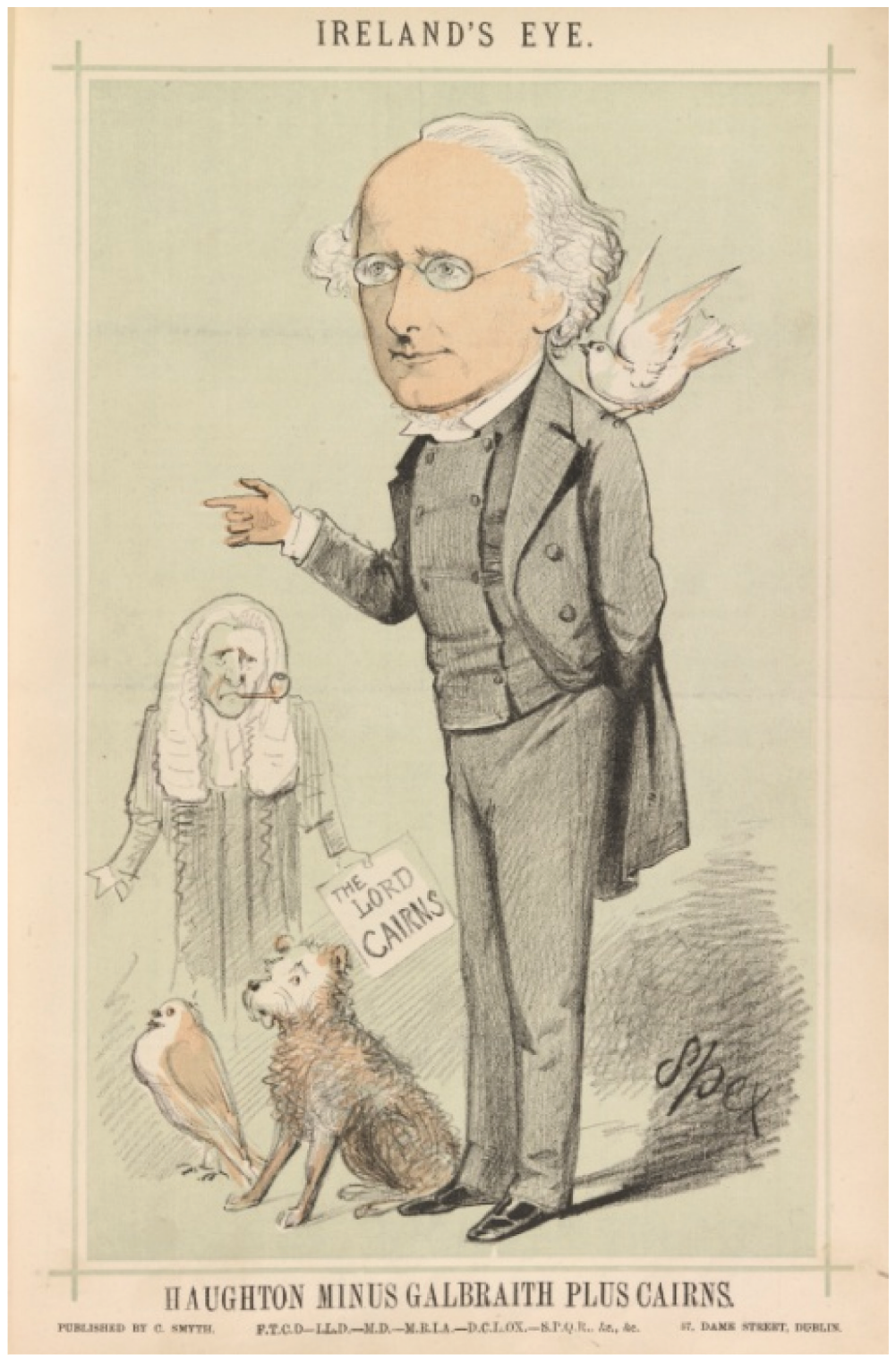

FIG. 2-'Galbraith and Haughton minus Galbraith plus Cairns', as shown in Ireland's Eye, 3 October 1874, 104. At the time the Right Honourable Baron Hugh Cairns McAlmont was the Chancellor of the University (College Calendar for 1874).

Speaking of James Haughton (1795-1873), the social reformer and vegetarian, they say 'He married (1822) Mary Anne Barcroft (1795-1829) of Cork; they had a son, the polymath Samuel Haughton (qv), and four daughters, one of whom, Mary Anne, married the economist William Neilson Hancock (qv).' This is incorrect, as Samuel Haughton FRS was the son of Samuel Haughton (1787-1877) of Burrin House, Carlow, and Sarah Hancock (1787-1861) of Lurgan. Jessop (1973) had already warned about the complexities of the Haughton pedigree (see note 1 above). 
married in Carlow on 10 April 1817. Their children were John Hancock Haughton, Dora Hewetson, Fanny King, Samuel Haughton, Louisa Haughton (who did not marry), Elizabeth-Anne Haughton (Isabel), who married Samuel Robert Graves, mayor of Liverpool in 1860-1 and M.P. for the city in 1865, and Harriet Haughton, who married Anthony Elly Graves. ${ }^{11}$ Samuel junior entered Trinity College at the age of sixteen, graduating in 1843 with a gold medal. $\mathrm{He}$ was elected a Fellow in 1844, at the same time as Revs Galbraith and James McIvor. ${ }^{12}$ He married his half-cousin Louisa in 1848 and had four sons and two daughters, one of whom died in infancy. ${ }^{13}$ Louisa died in $1888,{ }^{14}$ and from then on his spinster sister ran the Haughton household. He was appointed Professor of Geology in 1851, holding the chair for 30 years, and obtaining his MB and MD in $1862 .^{15}$

Thus both Haughton and Galbraith entered Trinity College at the age of sixteen, were made Fellows at the same time and at a very young age, and were both gifted at applied mathematics. Both were converts to the established church, became professors, had large families and, as was frequent at the time, outlived their wives. Both had entered the University Lodge 33 at its foundation in March 1871 and progressed in the Masonic Order, and were churchmen of convenience in that they accepted ordination but did not adhere to preaching of an ascetic or pious nature. ${ }^{16}$ Their friendship, which was tested through many

11 About the Haughton family, see: www.gravesfa.org/migration.html (25 May 2011), also Leslie's biographical index, Church of Ireland clergy 614.2477 (see note 4) and Jessop (see note 1).

12 Leslie's biographical index, entry for Samuel Haughton.

13 Haughton's six children were Samuel, (born 1849), John (1851), Thomas (1853) and William Steele (1869). The latter became a well known orthopaedic surgeon and pioneer radiologist in Dublin. Major Samuel Haughton Galbraith married one of the Galbraith daughters, and Louisa Haughton married William Connyngham Ashe, a lawyer who moved with his family to Ceylon. Sources are Jessop (see note 1) and Leslie's biographical index, 477 (see note 12).

14 T.D. Spearman, 'Haughton, Samuel (1821-1897)', in DNB, online edn (Oxford, 1979), available at: www.oxforddnb.com/view/article/12616 (24 November 2010).

15 Obituary, British Medical Journal 77 (1897), 1376-77. Here it is stated that Haughton entered the School of Physic at Trinity College as a mature student for the purpose of reforming it.

16 The names of both men are entered into the minutes of Lodge 33, page 1, Masonic Hall, Molesworth Street Dublin 2. Although both men were remarkable public speakers, references to either Galbraith's or Haughton's sermons are few, and the mentions refer to just one or two sermons from each, preached for academic occasions. Two sermons on 'The gospel of nature' and 'The death of Christ' were preached by Haughton in Cambridge, apparently on the same day (22 May 1881) and probably in Dublin as well, and were printed in Dublin at the University Press, by Ponsonby and Weldrick, 1881. Neither sermon had much emotional appeal, and the theology was also commonplace. Neither Galbraith nor Haughton published a collection of sermons, as for instance George Salmon did. 
difficulties confronted simultaneously, was sealed by the marriage of one of Haughton's sons to one of Galbraith's daughters. ${ }^{17}$ In the late 1860s their occupations and interests began to diverge; Galbraith veered towards party politics and the administration of church property, while Haughton continued to pursue scientific research and the reform of medical education in Ireland.

The scientific manuals

Shortly after graduating, Galbraith, Haughton and two other Junior Fellows began a course of lectures to prepare young men for the entrance examinations to the artillery and engineers branches of the military academy in Woolwich, and the Indian civil service. Their students were highly successful at obtaining these positions, but in 1851 the classes were discontinued at the request of the Board of Trinity College, ${ }^{18}$ and the two men directed their energies on the preparation of scientific manuals. The authors each had at the time 20 years experience in undergraduate teaching.

The gratitude felt by those who benefited-directly or through the manuals - from their teachings, is touchingly expressed in a letter from Aubrey White, then Assistant Commissioner to John Dickinson, barrister at law, which was found among Galbraith's papers in Trinity College, ${ }^{19}$ dated 24 October 1888, and written at the Crown Lands Department, Toronto, Ontario, Canada:

In reply to your letter of 19 instant, I beg to inform you that the townships of Galbraith and Haughton in the district of Algoma in this province were named after the two distinguished fellows of Trinity College Dublin. One of the officers of this department had the pleasure of attending their lectures in TCD over 30 years ago. Their works on astronomy and trigonometry are used as text books in this province.

An anonymous obituary of Galbraith, published in the Daily Express and titled 'Galbraith and Haughton', states:

For many years, basic textbooks that were the product of their joint industry, were current in all Irish schools; "Galbraith and Haughton's Euclid", "Galbraith and Haughton's Algebra", etc were the well planned avenues by which most young Irish men were conducted to the mysteries of these sciences. ${ }^{20}$

17 This is illustrated in detail in Galbraith's diary entry for 16 July 1850. In Haughton's funeral report in the Irish Times, 4 Nov 1897, 5, one of the floral tributes read; 'In loving remembrance from Galbraith's children-J. Major, H. Galbraith, S. Galbraith and S. Haughton Galbraith'. The last named was Major Samuel Haughton Galbraith, eldest son of Samuel Haughton (see note 13) who died on 28 January 1924.

18 Daily Express, 21 October 1890 (TCD-JAG-MSS 3865/4/13).

19 Daily Express, 21 October 1890 (TCD-JAG-MS 3856/4/13).

20 Daily Express, 21 October 1890 (TCD-JAG-MS 3856/4/13). 
The series is well worth a separate study, but a preliminary enquiry indicates that it came to comprise twelve titles (Table 1), which began to appear in 1851. By the early 1870s, most of its titles were published in multiple editions - four, six, seven and in one instance, fifteen editions. Considering an average of 4,000 copies per edition - the number of copies is stated in the front page in some, but not all of them-Table 1 suggests that around 300,000 individual textbooks were produced between 1851 and the late 1890s. Several publishing houses were involved successively in the business, including Hodges and Smith, Longman, Brown and Green (from 1854 to 1868), and Cassells, Petter and Galpin (from 1868 to the early twentieth century), with offices in Dublin, London, Melbourne, New York and Paris. Given that Galbraith was the poorer of the two men, that he married in 1850, that the first volume of the series appeared in 1851, and that in some early volumes he appeared as the sole author, it can be conjectured that the series was initially his creation and a means to make some money when his family was young, with Haughton joining in later. Advertisments for the manuals, as well as for other books by local authors, featured in the Yearly Calendar of the University of Dublin between

TABLE 1-Galbraith and Haughton's editions and sales of the titles in their Mathematical series*

\begin{tabular}{|c|c|c|c|c|c|}
\hline $\begin{array}{l}\text { Title: Manual } \\
\text { of... }\end{array}$ & $\begin{array}{c}\text { lst } \\
\text { Longmans } \\
\text { edition }\end{array}$ & $\begin{array}{c}\text { Other known } \\
\text { Longmans } \\
\text { editions }\end{array}$ & $\begin{array}{l}\text { Total no. sold } \\
\text { by Longmans } \\
(1854-68)\end{array}$ & $\begin{array}{l}\text { Other } \\
\text { Cassells } \\
\text { editions }\end{array}$ & $\begin{array}{l}\text { Last known } \\
\text { Cassells } \\
\text { edition }\end{array}$ \\
\hline Mechanics & 1854 & 5 th $1866 \times 9000$ & 10141 & & 11th 1890 \\
\hline Optics & 1854 & 4th $1860 \times 4000$ & 4572 & & 1892 \\
\hline Hydrostatics & 1854 & 3 rd $1859 \times 4000$ & 5283 & & 9th \\
\hline Trigonometry & 1852 & & 10581 & 1869 & 14th 19-? \\
\hline Arithmetic & 1854 & 4 th $1862 \times 4000$ & 7333 & & 6th 1871 \\
\hline Astronomy & $1856 \times 2000$ & 2nd $1857 \times 2000$ & 5598 & & 3rd 1869 \\
\hline Euclid I-III & 1854 & 5th 1857 & 8045 & & \\
\hline Euclid IV-VI & $1859 \times 4000$ & 5th 1863 & & & \\
\hline Algebra & 1860 & 1864 & 3426 & 1869 & 15 th \\
\hline Maths. Tables & 1860 & 3rd 1863 & 4264 & 1868 & 14th 19-? \\
\hline Steam Engine & 1864 & & 1435 & & \\
\hline $\begin{array}{l}\text { Tides \& } \\
\text { currents }\end{array}$ & 1862 & & 218 & & 4th 1870 \\
\hline Total: 12 titles & & & 60,896 books & & 86 editions \\
\hline
\end{tabular}

NB: Data obtained from online searches of the catalogue of Trinity College Dublin Library, as well as from the Catalogue of the Science Library in the South Kensington Museum (London, 1891). Where known, the data for each edition are given in the form; edition number, date and number of copies printed (ie $\times 4000$ ). The Longmans' sales figures were obtained from the Longmans' Archive, Special Collections, University of Reading, United Kingdom, but please note that data for 1855-6 and 1857-8 were not found, so are not included. The figure for 'Euclid' includes books I to VI combined plus other minor editions. Similar archives for Cassells have not been found. 
Joseph Allen Galbraith
1852 and $1859,{ }^{21}$ which provided discreet publicity for 'Hodges and Smith', a traditional Dublin booksellers that for many years was based at 104 Grafton Street. Galbraith and Haughton's Mathematical series sold into the early years of the twentieth century.

Galbraith's life's work can be divided into four notional phases which, aside from the first, ran in part concurrently. These were; first, the stage of preparatory work (1834-56), some aspects of which we have considered above, running from his entry into Trinity College to the Angeli case which we will see below; second, his involvement in the academic and administrative life of the College, as a scientist and member of many public bodies, concluding with his years as an innovative bursar during 1881-2, and as registrar of the college; third, his work with the Home Government Association from its foundation in the summer of 1869 to Galbraith's death in 1890; and fourth, his career in the Church of Ireland, in particular his contribution to the orderly process of its disestablishment and disendowment in the early 1870 s, and his charitable works, notably with the Masonic Orphan Girls School in Ballsbridge, Dublin 4.

The Angeli case, like the scientific manuals, involved both Galbraith and Haughton, but it is clear from the proceedings ${ }^{22}$ that Galbraith was the leader of the small band of scholars who took action in defence of academic standards and the reputation of the university. The case was heard in 1856 at the Kildare Summer Assizes when Galbraith brought Signore Basilio Angeli, Professor of Italian and Spanish at Trinity College Dublin, before the Lord Chief Justice, accusing the plaintiff, among other things, of not knowing the Italian language but being rather 'a stucco merchant'. Counsel for the plaintiff was Isaac Butt, QC. The trigger was the Italian translation that Angeli had made of a short speech that Professor Kane of Queen's College Cork had requested before sending it to the printers. Galbraith, Haughton and Ingram detected 31 grammatical and spelling errors in Angeli's Italian translation. Angeli's written English appears to have been equally appalling, judging by the notices he posted for the students. Eventually after a second trial the three fellow defendants, of whom Galbraith was the most senior, won their case, but had to pay costs to the tune of $£ 3,000$. Signore Angeli was dismissed from his post. On his return to Trinity College, Galbraith's students spontaneously rewarded him with a handwritten petition in support, with 500 signatures appended, which was presented to him at an informal ceremony in the examinations hall.

These early years were also dedicated to his career as a naturalist. In 1845 Galbraith was elected a Member of the Royal Irish Academy, and he

\footnotetext{
21 University of Dublin Yearly Calendar for 1855-80 (Dublin).

22 Galbraith, 1818-90, defendant (1857), Action for libel: report of the case of Angel v. Galbraith as tried before the lord chief justice at the Kildare assizes, 1856; and before the lord chief baron in the Court of Exchequer, at the after-sittings, Michaelmas term, 1856; specially reported by William $R$. Furlong, with an appendix of original documents (Dublin, 1857).
} 
contributed four scientific publications to the Proceedings of the Royal Irish Academy. ${ }^{23}$ His active participation at the Academy lessened after 1856, well before his involvement in Home Rule began in 1869. His scientific papers are of a geological and meteorological bent, such as Haughton could have inspired. They do not reveal any sustained research interests, though his use of mathematics points towards statistical and actuarial skills, rather than the talent of an innovative pure mathematician. The minutes of the Academy Council meeting for 8 March 1856 mention that 'a letter was read from $\mathrm{Mr}$ Galbraith complaining of an attack made upon his personal character at the last meeting of the Council' (which took place on 3 March, and had not been attended by Galbraith). The secretary was directed to inform Mr Galbraith 'that the expressions complained of emanated from an individual, and that the Council did not therefore hold themselves responsible for them'. ${ }^{24}$ In around 1857 Galbraith ceased to participate in Academy affairs and turned his attention to church administration and party politics.

Home Rule (1869-90)

On 19 May 1870, 49 gentlemen, the majority Protestants, among them Joseph Allen Galbraith, ${ }^{25}$ met in Dublin to discuss Ireland's future governing arrangements. They agreed to promote Isaac Butt's plan of federal home government, and the gathering constituted the nucleus of the Home Government Association for Ireland. ${ }^{26}$ Isaac Butt (1813-79) was the guiding light though he never intended the association to become a popular body modelled on the Repeal Association, which it became. The inaugural public meeting of the association took place in the Round Room of the Rotunda Hospital in Dublin, and an Irish Times report ${ }^{27}$ lists some of those in attendance and the speeches, which included an extraordinary contribution by Sir Dominic Corrigan, the

\footnotetext{
${ }^{23}$ Haughton and Galbraith, 'On experiments carried out in Dublin to determine the azymuthal motion of the plane of vibration of a freely suspended pendulum', Proceedings of the Royal Irish Academy 5C (1850-3), 117-77. Galbraith, 'On the relative quantities of potash and soda in the feldspar of the Dublin and Wicklow granites', Proceedings of the Royal Irish Academy 6C, 134-43. Galbraith, 'The barometric measurement of mountain heights', Proceedings of the Royal Irish Academy 6C (1853-57), 276-9. Galbraith, 'Tables and diagrams relative to the rainfall as observed in the magnetic observatory at Trinity College Dublin from 1850 to 1860', Proceedings of the Royal Irish Academy 7C (1857-60), 392-3.

24 Minutes of meeting of the RIA Committee 9 (1852-6), 317. The minutes do not give details of the nature of the alleged impropriety, if there was any, and the letter has not been found.

25 A photograph illustrating this meeting can be found in TCD-JAG-MS 3856/5.

26 Alan O' Day, 'Isaac Butt (1813-1879)', DNB, online edn, available at: www. oxforddnb.com/view/article/4222 (1 September 2009).

27 Irish Times, 'City of Dublin election', correspondence, 10 and 13 August 1870, 3, and 2 September 1870, 2.
} 
eminent Catholic physician, branding Galbraith an Orangeman, and Home Rule a 'secret society'. This was both unfair and inaccurate and it elicited an immediate response from Galbraith's friends, including a J. Kavanagh and James Haughton, ${ }^{28}$ and a personal response which was temperate with regard to his own commitments but passionate about the cause of Home Rule. 'Home Rule', incidentally, was a term invented by Galbraith to replace the more cumbersome Home Government, by which the group was known initially. ${ }^{29}$

Years later, in 1888, Charles Stewart Parnell invited Galbraith to run as a Dublin candidate for the Home Rule Party. ${ }^{30}$

A very general feeling exists among my colleagues that your candidature for the Stephen's Green Division would be a very strong one, and most acceptable to the constituency of public opinion in Ireland generally. Your addition to our ranks at this juncture would also be of the utmost importance and significance politically. It would tend to assuage the feeling of alarm undoubtedly existing amongst many of our Protestant fellow countrymen at the prospect of Home Rule, and it would afford another example of the spirit of toleration belonging to the bulk of the Irish Catholics. I need not say that your coming forward would be most gratifying to myself personally. Will you kindly give the matter your careful consideration and let me know what you think.

However, Galbraith's poor health, compounded by bitter disappointments and the death of his son Richard that year, precluded his accepting the invitation, and he died two years later, in October 1890, aged 72.

$\overline{28}$ Both responses in the Irish Times, 13 August 1870, 3.

29 Galbraith, as inventor of the words 'Home Rule', was mentioned in several newspaper obituaries, for instance in the Daily Chronicle and The Tablet, all in JAGP MSS-3856/3. See for example J.G. Seufe Mcneil, What I have seen and heard. The term Home Rule was officially acknowledged when Arthur Balfour, Chief Secretary for Ireland, referred to it for the first time in the notice of a motion for a parliamentary debate, but several authorities of the time attest that the talismanic words 'Home Rule', were coined and used first by Galbraith.

30 The first direct mention of Home Rule in the Irish Times was on 23 June 1873, but the change of terminology was not consistent and later reports referred variously to the 'Home Rule' or 'Home Government Association'. Irish Home Rule was modelled on Australian (see motion tabled by Galbraith to the meeting of the Home Government Association, Irish Times, 14 December 1870), where the colony became the master of its own destiny by having its own functional and independent parliament, while accepting an honorary and historically-based headship from Queen Victoria. In 1888 Galbraith contemplated running for election as a member of parliament for Dublin on behalf of the Home Rule Party. Charles Stewart Parnell wrote to him on 11 April of that year. 
Galbraith was elected Senior Fellow of Trinity College and bursar in 1880, and registrar in 1885 . He did not regard these appointments as honorary, but made considerable and lasting changes in the practices of the College, especially in his post as bursar. Up to then the college had followed a medieval system of accountancy. ${ }^{31}$

Galbraith was elected bursar on 20 April 1880, for the incoming year. We can follow developments in his own words from the policy paper he had printed outlining his ideas for the reform of the College's financial system. ${ }^{32}$ His predecessor in the job, Joseph Carson DD (FTCD 1837, vice-provost 1890), had held the office for the previous twelve years, and Andrew Searle Hart (1811-90), Carson's predecessor, had held it for another eight years (1860-8). On moving into the office, Galbraith found that there had not been left behind either cash book, day book, journal or ledger. The only books in use were the rentals and benefaction books, the quarterly accounts and the summary. These contained the expenses incurred during the quarter, with a view to settling the quarter's accounts and ultimately the annual accounts on 20 November. Recognising that there were no accounts books in the office that a book keeper would acknowledge as such, and that for the carrying on of business, as well as for his own protection, the sooner he started the journal and ledger the better, he lost no time, journalising every transaction in 'Cr' and 'Dr', and posting the entries into the ledger daily, so that every week he was able to make a trial balance, an operation essential to the safe conduct of business. At the end of each quarter he was able to provide a balanced account taken from the face of the ledger, and at the end of the year a balance sheet or financial statement in the form familiar to all accountants. This, however, turned out to be all in vain, when he was told that, in conformity with ancient practice, the auditor of the account assumed also the duty to prepare the annual account, and then audit it himself. 'This appeared to me to be a novel proceeding. Nevertheless so great is the force of custom that I submitted, although I am sure that the practice is as illegal as it is absurd'. Shortly before the end of his tenure he laid before the Board printed copies of a statement as to the business of the bursar's office, with suggestions for its efficient and safe discharge for the future.

Galbraith kept the journal and ledger down to the last day of his tenure, 20 November 1882, and passed them on to his successor, John William Stubbs $\mathrm{DD}$, who, upon entering the office of bursar, threw them aside and restored the old system.

The Board officially read Galbraith's statement on 11 November 1882, and ordered it to be circulated to all their members. In the statement, Galbraith noted that the age of bursars had been steadily increasing, since they were elected

31 TCD-JAG-MS 3856/1/, Parnell to Galbraith, 11 April 1888.

32 Galbraith, Reform of the method of keeping the accounts of Trinity College Dublin (and related topics) (Dublin, 1885), Trinity College Library, Early Printed Books, GALL. RR.30.29. 
from the ranks of the Senior Fellows; and as such nomination could only be bestowed on Fellows who had reached the age of 65 years, he estimated that the age of bursars was bound to increase in the following decade. He also mentioned how the office of bursar was becoming increasingly complicated, in the light of new legislation regarding rent charges, Poor Law, Income Tax, Land Courts, and also the increased numbers of salaries to be paid, examination fees, trust funds, mortgages and investments to be administered, and printing press business to be conducted. Bestowing such a complex job on an inexperienced 65-year-old man accountable for a yearly business worth approximately $£ 80,000$ was to prove extremely unpopular. Galbraith also reviewed how different governments and large public and private businesses kept their accounts and pointed out that even Oxford University used the double entry system. He recommended first that accounts be kept by the system of double entry; second, that a qualified book keeper be employed to assist the bursar; and third that the bursar's cheques be signed also by another Board member. On 20 February 1883 the statement was brought to the Board, who, after further consideration, deferred their decision. Objections were made that the use of double entry would cause increase of labour; that it would involve great additional expense; that the present system had served well for many years, and that it should not be changed; that if there was an advantage to double entry it should be used alongside the old system; that the adoption of the double entry system would require changes in the statutes of the College, and that there were certain kinds of business to which double entry was not suited, the College being one of them.

Galbraith requested a new meeting of the Board to be held on 7 February 1884. In advance of this date, Stubbs was reappointed bursar for a second year. Haughton, who attended the proceedings, tried to help by proposing minimal amendments. The assistance of $\mathrm{Mr}$ Whitton, accountant for the Representative Church Body, was sought to judge the soundness of Galbraith's advice. Whitton was fully supportive of Galbraith's proposals, and eventually his recommendations were adopted by the College in full.

\section{Churchman $(1846-90)^{33}$}

College practice at the time demanded that Fellows should take holy orders from the United Church of England and Ireland, and Galbraith did so in 1846, with an eye on the development of his academic career. Although his diaries ${ }^{34}$ reveal that he was an assiduous church-goer, after his early years he seldom preached. He was generally interested in religious issues and his diaries record him visiting Lourdes, the site of the alleged apparitions of the Virgin Mary in

${ }^{33}$ Galbraith and Hamilton (Honorary Secretaries), Report of the Proceedings of the Dublin Diocesan Synod at its second session (Dublin, 1871). Throughout the late 1860s the Irish Times carried detailed accounts of the frequent debates at the Church Representative Body, including many of Galbraith's interventions.

34 Galbraith Diaries, TCD-JAG-MS 3824-3855. 
1858. He was a prominent freemason. ${ }^{35}$ Initiated in the Shakespeare Lodge No. 143, Dublin, on 10 June 1868, he subsequently joined the Duke of York Lodge No. 25 in Dublin on 2 April 1870, the Union Lodge of St Patrick No. 357 in Downpatrick, on 2 November 1870, and was a founding member of the University Lodge No. 33 in Dublin, on 7 February 1871. The 1885 calendar for the Grand Lodge of Free Accepted Masons of Ireland mentions him, together with Lord Plunkett, Bishop of Meath, as Grand Chaplains. However, as he had to be re-elected every year, he encountered a growing body of opposition because of his political views, which were liberal towards Catholic nationalists. He eventually abandoned the position, deciding that it was not worth the yearly round of confrontation. ${ }^{36}$ From then on he concentrated his attention on the development of the Masonic Orphan Girls School in Ballsbridge, Dublin 4, for which he had chaired the fundraising committee and attended the ceremony of laying the foundation stone in $1880 .{ }^{37} \mathrm{He}$ visited the school regularly, and derived great pleasure from organising fund-raising functions or attending them, and seeing it develop. ${ }^{38}$

Gladstone's Church Disestablishment Act of $1869^{39}$ dissolved the Union between the Church of England and the Church of Ireland, with effect from 1 January 1871. It determined that the Church of Ireland should be disestablished and disendowed, that the grants and other financial support to the hitherto established Church of Ireland should be withdrawn and that its property, valued at $£ 16$ million, after satisfaction of all just and equitable claims, should be applied for the advantage of the Irish people'. The geographic unit, the parish, would be sustained by subscriptions from the local faithful. This created rich and poor parishes, and a fair transfer system was needed. A system of pensions was also needed, as well as a fund for the care of ministers' widows and orphans. Such massive change entailed not only administrative but doctrinal, liturgical and financial reforms that had to be carefully planned, involving both clerical and lay faithful. The commission of church temporalities

35 Dublin Grand Lodge Minutes, July 1879-March 1901. Also, Calendar for the Grand Lodge of Free and Accepted Masons of Ireland, 89, list of Officers for the year 1885, Molesworth Street, Dublin 2.

36 Freeman's Journal, 21 October 1890 (TCD-JAG-MS 3856/4/18).

37 His letter of resignation can be found on page 351 of the Grand Lodge Minutes (see note 35). Freeman's Journal, 21 October 1890 (TCD-JAG-MS 3856/4/18) also alludes to this incident. However, other prominent nationalists such as Isaac Butt, or Haughton himself, who were also masons, do not appear to have suffered in the Order on account of their political views.

38 See Galbraith Diaries, TCD-JAG-MS 3846, entries for 23 and 24 June 1880. Galbraith's committee had collected $£ 2724$ of the $£ 12,000$ needed. The Freeman's Journal on 25 June reported the laying of the foundation stone and speeches in great detail.

39 Michael Partridge, Gladstone (London, 2003); also Robert Brendan McDowell, The Church of Ireland 1869-1969 (London, 1975), 26-50. 
was established to manage the property of the church. On the issue of salaries, a holder of an ecclesiastical benefice was to be entitled to his net income for life, so long as he continued to perform the duties attached to the benefice; so too were diocesan schoolmasters, sextons and parish clerks. A cleric in receipt of an annuity could commute his life interests for a capital lump sum, calculated on his expectation of life and net ecclesiastical income, which would be handed by the church commissioners to the Representative Church Body. In 1870 Galbraith and other Trinity College scholars, such as Rowan Hamilton, George Salmon, Reeves and Lloyd, were co-opted for the proceedings of the Dublin Diocesan Synod, ${ }^{40}$ to which Galbraith contributed extensively. ${ }^{41} \mathrm{He}$ was also requested to join the Representative Body, through which he helped to frame the whole scheme of the distribution of its endowments among the clergy, by calculating the income to which every Church of Ireland cleric was entitled. As secretary of the Synod, Galbraith duly reported the proceedings.

In spite of his faithful contributions to the identification of many technical problems at this critical juncture, Galbraith was expelled from the Representative Body in the winter of $1887-8$ on the grounds that his involvement with Home Rule was incompatible with his membership of the Representative Body. The reasoning for the expulsion was conveyed to him privately by letter ${ }^{42}$ from the Archbishop's Palace, Armagh, by the then Archbishop Robert Bent Knox (1808-93). Both men dealt with the affair with mutual sympathy and as a technical issue, but doubtless the episode left its scars. The difficulty was partly personal, and a matter of principle. The Home Rule Party had emerged from the National League, an illegal organisation which was plainly hostile to the rights of property and landowners, and the Church of Ireland was one such landowner. The incompatibility between occupying a position in the Finance Committee of the Church Representative Body and the anti-property stance of the National League was evident, and much as Galbraith's former work for the church had been appreciated, he was

$\overline{40}$ Report of the proceedings of the Dublin Diocesan Synod at its second session, 1871/ prepared for presentation to the General Synod by Rev. Joseph A. Galbraith and Henry Alexander Hamilton, Honorary Secretaries. Church of Ireland. Diocese of Dublin. (Dublin, 1871).

${ }^{41}$ McDowell, The Church of Ireland, 99. The correspondence of Knox-Galbraith on the latter's forced resignation from the Church Representative Body (the Knox letters) was conducted privately, and can be found in TCD-JAG-MS 3856/1/8, 9, 11. The Knox letters were signed from The Palace, Armagh, and were written on dates in December 1887 and January 1888. The tone is amicable at a personal level although Knox was the bearer of bad news, namely Galbraith's dismissal. The hostility of the official Church of Ireland towards nationalism, Home Rule and Parnell comes across in particular in the Irish Ecclesiastical Gazette.

${ }^{42}$ The correspondence of Galbraith-Parnell on amendments to the Land Bill going through at the time compelling Trinity College to sell College Estates to a middleman (TCD JAG-MS 3856/1). 
requested to resign his positions in the church. Besides, if they were to discuss possible actions against the League, they would have to do so with one of its members in their midst. There appears to have been no personal bitterness between the two men, as Galbraith took the action with characteristic gentleness, and he continued to serve the church despite his new reduced status.

The difficulty with the Church of Ireland's ownership of lands had arisen earlier between Galbraith and Parnell, after the Act of Disestablishment, with regard to the grounds occupied by Trinity College Dublin. On 24 May 1881 Galbraith had written to Parnell at the House of Commons in connection with the Land Act that was being prepared, ${ }^{43}$ suggesting an insertion in the Land Bill of a clause reviewing the terms of ownership of the College Estates. This act was still being drafted in $1886 .{ }^{41}$

Joseph Allen Galbraith died at his home at 46 Lansdowne Road, Dublin 4 and is buried in Mount Saint Jerome Cemetery in that city. He left assets to a value of $£ 7,185,6$ s and $8 \mathrm{~d}$. The details of the will are lost. In the obituaries in the Irish Ecclesiastical Gazette on 24 October $1890,{ }^{44}$ both the Dean of St Patrick and the Dean of Christchurch mentioned that there had been differences in the past between each of them and Galbraith, but that all was then forgotten. It was proposed that a bust of Galbraith be commissioned for Synod Hall, but this brought fresh controversy, ${ }^{45}$ as some of Galbraith's loyal friends were not satisfied with a mere bust bearing his name and dates, but sought an explicit apology from the official authorities. No bust or plaque can be found and, presumably, none was ever made.

\section{Samuel Haughton Wide-ranging interests and sustained scientific output}

Samuel Haughton is best known for having been at the forefront of the early wave of Irish anti-Darwinism, ${ }^{46}$ and the initially slow arrival of Darwinism to Trinity College is due to his opposition to the teaching of evolution. He was by no means

\footnotetext{
43 TCD-SH-MS 10716/19, 22 March 1886, from the 'Select Committee to enquire into and report upon tenure of lands under Trinity College Dublin, and the Provost thereof, and the workings of TCD Leasing and Perpetuity Act, 1851, with respect to the variation of rent and its effect on the value of the interests respectively of the College, the perpetuity grantees, and the occupying perpetuity tenants of the lands'.

44 Obituaries in Irish Ecclesiastical Gazette, 24 October 1890 (TCD-JAG-MS-3856/3).

45 F.F. Carmichael, to the editor of the Daily Express (undated) (TCD-JAG-MS-3856/ $3 / 20)$.

46 N.D. McMillan, The Rev. Samuel Haughton, a man of great erudition and a determined opponent of the theory of evolution (Carlow, 1979). Richard England, 'Natural selection before the Origin: reactions of some naturalists to the Darwin-Wallace papers (Thomas Boyd, Arthur Hussey and Henry Baker Tristram), Journal of the History of Biology 30 (1997), 267-90. Samuel Haughton is dealt with interestingly in the footnotes. Peter Bowler, 'Charles Darwin and his Dublin critics: Samuel Haughton and William Henry Harvey', Proceedings of the Royal Irish Academy 109C (2009), 409-20.
} 
alone in his opposition in the College in the early $1860 \mathrm{~s} .{ }^{47}$ While he might have been reluctant to accept Darwin's ideas on species origins, he justified his position on scientific and observational grounds, while Darwin's propositions, based on a then non-existent fossil record and on rather intangible selective forces which were human-like in nature, appeared less grounded in hard facts than speculative.

Haughton's attitude to Darwin is often considered in isolation from his other work, and it overshadows the other talents that he deployed with characteristic energy. I will focus here on his administration and management of Trinity Medical School (or School of Physic) and of the Royal Zoological Society of Ireland. Two other subjects touch on these, and will be considered briefly: his contribution to the vivisection debate, and his activity as editor of Irish natural history journals. His attitude towards Darwinism will be briefly discussed in this context. Unfortunately, other obvious themes such as his contribution to geology and palaeontology, or his major work on animal mechanics, must be left for another day.

\section{Reform of Trinity Medical School.}

Haughton's obituaries in the British Medical Journal ${ }^{48}$ and in the Proceedings of the Royal Society ${ }^{49}$ trace his medical career, paraphrased as follows;

Having graduated with an MD in 1862 at the age of 40, after a professional career in mathematics and geology, Haughton set himself vigorously to reforming the abuses of the school and to strengthen its weaknesses. The school had suffered from being governed by the Board of Trinity College, who were unsympathetic and knew little about medicine, and because the staff had become slack, while the machinery of the school was inefficient. Through his energy and practical wisdom he soon brought about a new state of things, and eventually raised the school to the place it now occupies as the leading medical school in Dublin. New blood was brought into the teaching staff, new buildings were erected, and teaching facilities improved out of the College's revenues.

It is possible to flesh out this overview from Haughton's papers. ${ }^{50}$ These were times when the medical profession was becoming more organised

\footnotetext{
47 Miguel DeArce, 'Darwin's Irish correspondence', Proceedings of the Royal Irish Academy 108B (2009), 43-56. Among other Trinity scholars who were initially in disagreement with Darwin's theories are the botanist William Harvey, the entomologist William Haliday, the geologist Joseph Beete Jukes and the anti-vivisection activist (not from Trinity College). Frances Power Cobbe. This attitude softened gradually in time. 48 Obituary, British Medical Journal, 6 November 1897.

49 Proceedings of the Royal Society (1897) 62, xxix-xxxvii.

50 Haughton's collected documents for the McDowell affair can be found in Haughton, 'Memoirs pour servir. Medical School, Trinity College Dublin. January 1865-January 1879'. This is a standard hardback copybook, with the relevant printed documents pasted on its leaves. Other Haughton papers in the Old Manuscripts section of Trinity College Library are found in TCD-SH MS-10716/1-6. Of these, the most relevant to this paper are 10716/5 and 10716/6. These refer to a latter part of Haughton's career,
} 
throughout the United Kingdom, by means of acts of parliament, ${ }^{51}$ the separation of practical skills into different academic disciplines, training and the emergence of self-regulating professional bodies. ${ }^{52}$ From his administrative positions Haughton made valuable and long-lasting contributions to these issues as they emerged in Irish medicine. What follows is a digest of those documents.

Samuel Haughton was appointed registrar of Trinity Medical School in 1864 (3 June 1863), and remained in that post for fifteen years. In November 1863 the tutors convened a meeting to study the performance of the school, and on 7 January they sent a statement to the provost and Board of the College, recommending that a committee be formed, comprising George McDowell, Joseph A. Galbraith and Samuel Haughton to investigate the state of medical education, particularly in anatomy and physiology, in the rest of the United Kingdom, and in Trinity College in particular. They found that matriculation was low in Trinity College, with an average of 37.8 students per year between 1850 and 1863. The number of students involved in dissections in the school nearly doubled between 1859, with 57 students, and 1860, with 100 students. Benjamin D. McDowell, a brilliant teacher, popular with the students but neglectful of his teaching duties, ${ }^{51}$ was elected Professor of Anatomy in 1857, and his job was up for re-election in 1865. By contract, he was required to lecture four times a week between 1 November and 1 April each year, and to devote one additional hour per week teaching comparative anatomy. The report noticed that McDowell did not spend any time in demonstration and dissection, leaving that entirely to his assistants, although he received a stipulated amount of money from the three guineas the students paid per

throughout the 1880s and 1890s. TCD-SH-MS-3504/1/1-12 refer to mathematical and family notes. TCD-SH-MS-3504/2/1-8 refer to exam papers and technical notes on evaporation, MS-3504/5/1-7 to mathematical notes dating to 1857 , MS-3504/6/1-9 to diets for patients at Sir Patrick Dun's Hospital and other similar diets, MS-3504/7/1-7 to some charitable work on Lady McLintock and an invitation from the Royal Zoological Society to the opening of the Haughton memorial building in the Society's Gardens.

51 Haughton himself produced an abridged record of the legal path relating to the teaching and practice of medicine in the United Kingdom, with special reference to Ireland (partly from TCD-SH-MS-10716/33 and /41.): 'Professorship of Anatomy and Chirurgery created by Provost and Fellows of TCD 1837. His lectures not accepted by RCSI. First licenses in Surgery conferred by TCD in 1852. Medical Act 2 August 1858 included Master in Surgery on any university in the UK, but did not include licentiates from any University. Amendment Act to the above, moved by Trinity College, 23 March 1860. Licentiates in Surgery from Irish Universities were entitled to register. School of Physic (Ireland) Amendment Act 1867, opening the professorships of Anatomy and Chirurgery, Chemistry and Botany, in the University of Dublin to all persons irrespective of their religion, and regulating their conditions of work. Act creating the Regius Professor of Surgery in Trinity College Dublin'.

52 Royal College of Physicians and Royal College of Surgeons, copy of the draft petition for Charter and Power to grant degrees, Lancet, 2 July 1887 (TCD-SH-MS $10716 / 6 / 19$ and 10716/6/26). 
course towards these demonstrations. The Board had known this for years, and in 1861 decided that the regulations of the new professorship could be altered once McDowell's post came up for election again.

Haughton instituted yearly reports on the different sections of the school, where he as registrar monitored the attendance of professors at their lectures. As a result, he found out that Dr McDowell had been absent for 41 out of the 100 lectures due in the winter 1866-7, and from 74 out of the 152 sessions he was scheduled to give in his capacity as clinical surgeon in Sir Patrick Dun's Hospital, while in receipt of his full dissection fees there. By the third annual report of the registrar of the Trinity Medical School, the situation had been corrected, and it remained within acceptable limits for the next eleven years, albeit with some personnel changes. As a result of repeated failures to comply with his teaching duties, McDowell was eventually dismissed, although he appealed several times offering different excuses. All this concluded in the School of Physic (Ireland) Amendment Act 1867, following which the roles and duties of professors of anatomy were regulated. ${ }^{53}$

Until the 1850s the disciplines of medicine and surgery went separate ways, each providing their training schedules and qualifications independently. In November 1887, during Haughton's tenure as registrar, the Royal College of Surgeons in Ireland, and the Royal College of Physicians, following the example of their London counterparts, lodged petitions to Queen Victoria for a charter and the power to grant degrees in surgery. This proposal was regarded, not only in the Trinity Medical School, but also in Edinburgh, Glasgow and Aberdeen, ${ }^{54}$ as having the potential to lower the standards of the medical profession, by reducing surgeons to mere mechanics, as their training must now be exclusively surgical. This prospect was compounded by the fact that the Royal College of Surgeons did not recognise the lectures given by Trinity College, with the result that it became necessary for Trinity College graduates either to pay double for their surgical qualifications in Dublin, or to seek them elsewhere. The Medical Act of 2 August 1858 did not include licentiates in surgery from the universities, but this was amended by the strenuous efforts of Trinity College (Amendment 23 August 1860). Trinity College also led the way in granting degrees in midwifery, conferring the first degrees in 1877, and in state medicine (or public health) ${ }^{55}$ in 1890 . The first exams were held in 1893 , and were taken by two students, who failed. Haughton had been an advocate of university education

53 The confrontation between the Board and McDowell is narrated in T.P. Kirkpatrick, History of the medical teaching in Trinity College Dublin and of the School of Physic in Ireland, Vol. 2 (Dublin, 1912). The relevant correspondence was collected by Haughton in 'Memoirs pour servir' (Press E, 1.9 in Early Printed Books, Trinity College Library). See note 50 for a description of this document. A letter from Haughton to the British Medical Journal on 26 February 1870, 223, refers to older bribery scandals that had occurred in the College.

54 For a summary see: www.irishstatutebook.ie/1961/en/act/pub/0021/gen_4.html (21 September 2010).

55 TCD-SH-MSS 10716/6/44 and /46, and TCD-SH-MSS-10716/6/33, no 8. 
for women, in the Trinity Medical School in particular, since the $1860 \mathrm{~s}^{56}$ The Dublin Hospital Act (1887), re-constituting the Medical Board, replaced the old annual grant of $£ 15,850$ for the support of certain hospitals in Dublin with a new grant of $£ 400,000$, as part of a plan to standardise the training and practice of medicine throughout the United Kingdom. In 1891 Haughton was also involved in overseeing the amalgamation of St Mark's Ophthalmic Hospital at the Lincoln Gate entrance to Trinity College, and the National Eye and Ear Infirmary at Molesworth Street. ${ }^{57}$ The College prudently postponed the merger until an entirely new building-the current Royal Victoria Eye and Ear Hospital, Adelaide Road, Dublin — was ready.

\section{Royal Zoological Society of Ireland}

Haughton's contribution to the Royal Zoological Society of Ireland (RZSI) was also very rich and persevering. ${ }^{58}$ The meetings of the Society used to take place on Saturday morning, and Haughton attended them religiously, first as an ordinary member; then as secretary from 1864 to 1884, and finally, from 1885 to 1889 , as president. Two serieses of private record books were kept. The Transactions books ${ }^{59}$ and the minutes of the weekly Council meetings. The Transactions book from March 1873 to April 1874 report of the following animal carcases being bought by Rev. Haughton: a male tiger (for £7), lion (£11.50), prairie dog, Bantam Eagle, green monkeys, Reston monkeys, python, ostrich, wolf, otter, heron, badger, marten, fox, seal, macaque, crane and pelican. Haughton published the second edition of his Animal Mechanics in $1873,{ }^{60}$ and it is possible that he was contemplating a third edition, as the opportunity for fresh observations offered itself so abundantly.

The minutes books enter for every meeting the date, the chairman and Council members in attendance - a majority were medical doctors - apologies, guests, details of accounts, details of numbers of visitors according to category (different entry fees were charged), and the different committees reporting any initiatives to increase the number of animals on show, or any potential purchases or sales. For instance, on 24 October 1868 a letter was read from the earl of Mayo

\footnotetext{
56 Kelly, Laura, 'Irish Medical Women, c. 1880s-1920s', unpublished PhD thesis, National University of Ireland, Galway, 2010.

57 See TCD-SH-MS 10716/35-38 on the amalgamation of St Mark's Hospital and the National Eye and Ear Infirmary.

58 The records of the Royal Zoological Society of Ireland can be found at TCD-RZSIMS 10608 in the Old Manuscripts section of Trinity College Library.

59 These started in April 1862, and they record daily observations on the health of the animals, causes of death and the disposal of the carcass - it had been decided that on the death of an animal a circular letter would be sent to all the Dublin medical schools to see if someone would be interested in purchasing the carcass to carry out a dissection, although most often it was Haughton who undertook the job-the animal's appetite and suggested changes to diet, and donations of animals, or animal carcasses, to feed the carnivores.

${ }^{60}$ Samuel Haughton, Animal Mechanics, 2nd edn (London, 1873).
} 
to the president of the society, Lord Powerscourt, promising to procure an elephant for the Zoological Gardens on his arrival in India as governor general. At a meeting on 5 December, news of the interest in an elephant had spread, as a Mr Rice from London offered an African elephant 4ft tall for $£ 250$, though Council rejected the offer. In his letter, Rice questioned the age of a pair of young lion cubs that he purchased from Dublin. The Council also heard at that meeting that the Gardens had received only 224 visitors that week, collecting only $£ 313 \mathrm{~s}$ $5 \mathrm{~d}$. Haughton, writing to them in his capacity as president of the Royal Geological Society, invited the RZSI to the rooms of the latter for a series of joint lectures to be held on the second Wednesday of the month in January, March, April, May and June, an invitation which they duly accepted. At the joint meeting on $10 \mathrm{March}$, a paper was read by A.W. Foot remarking on the fertility in confinement of some of the bigger carnivores. ${ }^{61}$ He pointed out that the first pair of lions had been obtained for Dublin Zoo for $£ 285$ in 1855 . Their first litter came in 1857, following which fifteen litters containing 62 lions had been whelped, of which nine died at or soon after birth, after sixteen weeks gestation, which was the normal gestation time also for the tiger, puma, leopard and ocelot. He noticed that while the tigress was likely to eat some of the litter, the lioness was not. By 31 March 1887, Dublin Zoo had registered 137 lion births, of which 91 had been exported. Haughton remarked that the tiger is stronger than the lion, because when it had been needed to restrain one of the tigers to cure his infected claws, it had required nine men to hold the animal, while the lion required only five menthe tiger's muscles are 45 to 50 per cent larger than their homologues in the lion. The gruesomeness of the operation, undertaken without anaesthetic, was brought to the attention of anti-zoo activists, one of whom, signing as 'Zoophylus' (Frances Power Cobbe used this pseudonym in some of her antivivisection writings) ${ }^{62}$ and writing for the Saunder's Newsletter, focused frequently on the RZSI and on Haughton's work.

After each Council meeting, a press release was sent to the newspapers, which reported it succinctly on the following Monday, quoting the numbers of visitors and amounts collected, as well as donations of animals and new members. If a new animal had arrived, a note was also sent for publication giving details of its behaviour or any other detail of potential interest to visitors. We can detect the hand of Haughton's interdisciplinary scholarship in the report, written a propos the arrival of new pups to the family of Egyptian

\footnotetext{
${ }^{61}$ A.W. Foot, 'Remarks on the fertility in confinement of some of the larger carnivores', delivered at the first joint meeting of the Geological and Zoological Societies, held at the Museum Building in Trinity College Dublin on Wednesday 10 March 1869. Over a period of sixteen years and in 23 litters, 92 lions were born in Dublin Zoo, 43 males and 39 females. In addition 23 cubs died young, under three to six months after birth (TCD-RZSI-MS 10608, Minutes Books, June 1872-February 1878). ${ }^{62}$ For Frances Power Cobbe signing as 'Zoophylus', see her autobiography; Life of Frances Power Cobbe as told by herself: with additions by the author and introduction by Blanche Atkinson (London, 1904). The note on Saunders Magazine about surgery performed on the tiger in Dublin Zoo without anaesthetic is signed by 'Zoophylus'. The notes on the pariah dogs were possibly penned by Haughton.
} 
pariah dogs, captured in the field of Tel-el-Kabir, and presented by Lieutenant Cusak. The note mentioned ${ }^{63}$ that 'these were the type of dog that ate up the body of Jezabel while Jehu was at his diviner. This should increase the popularity of these animals'. The note was titled 'An addition to the Gardens with a Scriptural association'.

Throughout its existence the RZSI often reported a negative yearly balance of a few hundred pounds, in spite of record numbers of visitors. For instance in 1845, under the chairmanship of Dr Whitley Stokes, 132,482 people were admitted at different rates, and the total income was $£ 1429$ 9s $3 \mathrm{~d}$ with a balance against the RZSI of $£ 106$. The RZSI had to borrow from its members, a loan that was gradually repaid, but there were long periods, like in the 1860 s, when repayments had to be suspended. Financial problems were commonplace throughout the life of the RZSI, and they were most acute during the winter months when the numbers of visitors per week dropped to the low hundreds. Haughton sought to change the entrance fee scheme to attract more of the onepenny entrants and to reduce the number of free admissions, but he was accused publicly of being elitist. The sale of animals was not enough to compensate for the loss of revenue, and the government's yearly grant of $£ 500$ was often delayed for long periods. Many schemes were undertaken to improve the situation, but none was a long-term solution.

\section{Other science-related concerns}

Science editor

Haughton's involvement with Edward Perceval Wright in the editing of the first series of the Natural History Review (1854-60), which formally wound up on 8 November 1862, has been described elsewhere. ${ }^{64}$ Galbraith was also involved in this project, but both withdrew so that Wright could make a clean break when offering the title to Thomas Henry Huxley in 1860. Unhappy with this development, Haughton immediately (in 1861) took over the production of another failing journal, the Dublin Quarterly Journal of Science, which published papers read before the Royal Dublin Society, the Royal Irish Academy, the Royal Geological Society and the Natural History Society. The Quarterly was targeted at 157 academic libraries in 111 cities in Europe and the United States. It lasted just six years (1861-6). Volume 6 opened with a paper on the antiquity of $\operatorname{man}^{65}$ by John Locke, which was really a retrograde overview on the history of the human race, dating its origins to 6,000 years previous, and based mainly on classical and Mosaic chronologies. It is surprising that Haughton the geologist would have bought into this narrow

63 Miguel DeArce, 'The invisible editor: Charles Darwin and the brief history of the Natural History Review (1854-65)', submitted 2011.

${ }^{64}$ Minutes of meetings of the accounts committee of the Natural History Review, personal communication from Patrick N. Wyse Jackson, October 2010.

65 John Locke, 'On the antiquity of man', Dublin Quarterly Journal of Science 6 (1866), 1-23. 
literalism, when at the British Association it was becoming clear ${ }^{66}$ that humans had coexisted with elephants in Britain some 60,000 years before. Tantalisingly, elephant teeth had also been found in Irish caves, ${ }^{67}$ but with no trace of human remains nearby. The Quarterly did not survive to the following year. The Journal of the Geological Society of Dublin, of which Haughton was also coeditor, was, although irregular, much longer lasting, as it spanned the years 1838 to 1889 . It was in this journal ${ }^{68}$ that Haughton recorded his first disagreement with the joint Darwin-Wallace paper on natural selection, published only six months earlier. ${ }^{6}$ His reasoning was gently put; ' . . to this (Darwin's and Wallace's views) there can be no objection, except that of lack of novelty...'; and further down, '... if it means what it says it is a truism, and if it means anything else it is contrary to fact'. Haughton also used volume 7 of the Natural History Review (1860) to restate his argument against the gradual evolution of species by attacking Darwin's proposition (presented in The Origin of Species) ${ }^{70}$ on the honey bees' use of wax in building their geometrically precise cells in the comb. While Darwin argued that in the honey bee the amount of wax used was minimised by the evolution of an instinct, Haughtoncharacteristically signing in Greek characters as Philonous - suggested that the regular hexagonal prisms emerged not out of an improved instinct for efficient use of materials, or by any design of the bee worker, but by physical necessity; if many bees were working together, each being the centre of an imaginary sphere. Inevitably if the spheres are of the same size they will pack in hexagons centred on another sphere, this being simply a physical constraint, not a selectable instinct. $^{71}$

${ }^{66}$ Charles Lyell, 'On the occurrence of works of human art in post-Pliocene deposits', Annual Report of the British Association for the Advancement of Science 29 (1859), 93-5, and C. Lyell 'On the antiquity of man, presidential address, Annual Report of the British Association for the Advancement of Science (Birmingham meeting, geology section, 1864), 9-74.

${ }^{67}$ E. Brennan and A. Carter, 'Notice of the discovery of extinct elephant and other animal remain occurring in a fossil state under limestone at Shandon, near Dungarvan, County of Waterford', Journal of the Royal Dublin Society 2 (1859), 344-57.

68 Samuel Haughton, 'Presidential Address' to the Geological Society of Dublin, 9 February 1859, printed in Journal of the Geological Society of Dublin 8 (1857-60), $152-3$.

69 C.R. Darwin and A.R. Wallace, 'On the tendency of species to form varieties; and on the perpetuation of varieties and species by natural selection', Journal of the Proceedings on the Linnean Society of London, Zoology 3 (20 August 1858), 46-50.

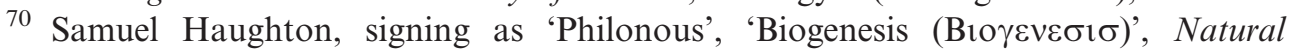
History Review 7 (1860), 20-5. This reasoning was expanded in Samuel Haughton, 'On the form of the cells made by various wasps, and by the honeybee, with an appendix on the origin of species', Dublin Quarterly Journal of Science 3 (1863), 35-47.

71 Charles Darwin, The Origin of Species (London, 1859). Darwin dealt with the cellmaking habits of the humble bee, the honey bee and the intermediate Melipone in Chapter 7. His extensive correspondence on the subject attests to his interest in the form of the cells of several species of bees and wasps for proving his idea of the gradual evolution of an instinct. 


\section{The vivisection debate}

In 1875 Haughton was well positioned to offer an informed opinion to the committee of the House of Commons enquiring into vivisection. He was registrar of the School of Physic in Trinity College, a doctor of Medicine, Fellow of the College of Physicians, the College of Surgeons and of Trinity College; a doctor of Civil Law at Oxford, and a Fellow of the Royal Society of London. For over a decade he had been secretary of the Royal Zoological Society that operated Dublin Zoo. His evidence before the 'Royal Commission on the practice of subjecting live animals to experiments for scientific purposes', is thus one of the longest (about 10,000 words) and most knowledgeable, nuanced and authoritative in the House of Commons Report. ${ }^{72}$ He objected to an instruction on 21 October, before Viscount Cardwell in the chair, and with Lord Windmardleigh, W.E. Forster, MP, Sir J.E.B. Karslake, MP, T.H. Huxley, J.E. Erichsen and R. Holt Hutton as examiners. Since he had been instrumental in the development of Lord Henniker's and afterwards Dr Playfair's antivivisection bills, it was inevitable that he would make known his strong opposition to the use of vivisection in the teaching of undergraduates, or simply to illustrate known experiments. He was, however, prepared to countenance certain experiments that were likely to yield new information, if carried out in the proper manner by a licensed researcher in an approved institution. This could require the use of live animals under no anaesthetic. He looked at the Anatomy Act of 1834 as a model of licensing that had put an end to the practice of body snatching, and made the dissection of certain corpses a legitimate practice in medical schools.

Houghton was asked about a Dr Purser, lecturer in Physiology at Trinity College, who had agreed to avoid the use of vivisection in his undergraduate teaching. Dr Purser had said that he regretted the Board interfering with his teaching by imposing a restriction; he would have preferred to have been trusted by them, but his objection did not mean that his teaching would have been improved by carrying out vivisections. Asked if not having vivisection experiments had been a handicap in his (Purser's) teaching, Haughton repeatedly replied that there was no loss to science, and that doctors did not gain much from vivisection. He mentioned the case of the effect of calomel on a dog's liver; doctors were prescribing 'blue pills' for people with liver problems, in spite of the fact that experiments on live dogs had shown that mercury was bad for their liver. Haughton also mentioned that in the process of regulating the practice of vivisection, physiologists alone were not the best judges; public opinion on the ethics of the experiments established and acted on by the regulator had to be consulted from time to time. Haughton pointed out persuasively that surgical training has always been done on corpses, not on living persons, and that the same applied to animals.

${ }^{72}$ House of Commons, 'Report on the Royal Commission on the practice of subjecting live animals to experiments for scientific purposes: with minutes of evidence and appendix' (London, 1876), 98-106. 
Conclusion
Galbraith and Haughton educated a generation of Irishmen in technical issues that would made them skilled and employable. This and other aspects of their work gave the two men a high social profile, although both combined modesty with confidence. They were also effective leaders and exemplified high ethical standards at work and in their private lives, in success and in failure.

Joseph Allen Galbraith had a brilliant academic career but it was clear from the start that he gave absolute priority to his ethical standards rather than to self-advancement, perfectly legitimate as this might have been. He initiated, with Haughton's support, the Angeli case against a fraudulent colleague, and just a few years later his and Haughton's respective roles were to be reversed, with Haughton pushing for improved standards at the highest level in the Medical School by instigating proceedings against the professor of Anatomy, while discretely supported by Galbraith. It was perhaps his unbending fidelity to high standards of fairness and justice that allowed him to acquire a broad understanding of Irish nationalism, to which cause he gave himself whole-heartedly, losing popularity among a small but influential group of peers. Technically, as a Church of Ireland clergyman, he was barred from running for election, but his party sought federation as an end to segregation, and he personally was immensely popular for his stance. Against the backdrop of today's cynical standards, we could say that he was too honest to be successful in politics, and too competent to be left aside entirely by his colleagues. He took in his stride personal rejection at the highest level, and it is perhaps at this point, and as a widower, that his friendship with Haughton became all the more valuable, although written evidence for this is lacking. Galbraith was able to commend himself to both Protestants and Catholics by serving both communities to the best of his rare mathematical ability and his personal charm.

Samuel Haughton was less openly party-political, but his own understanding of justice and fairness, as applied more narrowly to the fields of university education in Ireland-he favoured the official endowment of a chartered National Catholic University, ${ }^{73}$ medicine, education and the delivery of health care to the nation, and instituted the first course in public medicine in Ireland $^{74}$ - brought him to contribute his expertise to parliamentary debate and to the framing of laws, perhaps more effectively than his friend. Of the two, Haughton was the more politically astute, although he also advocated ideas that did not fit in with the orthodoxy of his peers. With hindsight, we can see now that he, like so many other religiously-motivated naturalists, failed to respond to Darwin's species theory with sufficient flexibility. An essential parallel in the life of both friends is their banishment from the political elite, and the subsequent obscuring of their memory.

When we consider Samuel Haughton's work across his lifetime, a fuller view of his achievement emerges. It can be enumerated as follows: 52 years as a productive member of the Royal Irish Academy, including five years as president; more than 20 years as a teacher and writer of scientific manuals;

${ }^{73}$ Haughton, University education in Ireland (London, 1868).

${ }^{74}$ For further details see Haughton, TCD-MS Memoires pour servir. 
30 years as a professor of Geology, publishing original work in many of its subspecialties; 25 years at the General Medical Council representing Trinity College's Medical School and introducing frequent improvements; 36 years of service as a Council member, secretary and later president of the Royal Zoological Society and Dublin Zoo, struggling to keep afloat an institution which in most countries depends on good weather for its success; nearly 50 years as a Trinity College Fellow; and more than 173 books and papers contributed to scientific journals, catalogued in the Royal Society of London, which at the time of counting reached only as far as 1883 . His ambitious project in "Animal Mechanics"75 opposing the idea of gradual evolution by natural selection, greatly bothered Darwin as it was not just speculative theology but well grounded in quantitative work 'done by myself'; Haughton's book, which was mathematics based, made Darwin feel out of his depth and unable to provide an adequate reply or criticism of the same kind.

No wonder Darwin asked himself how many 'Haughtons' there were in Dublin. The question was posed by Darwin to his friend Joseph Dalton Hooker in a letter dated $1862,{ }^{76}$ as he was puzzled that the author of a paper on the interaction between strychnine and nicotine, ${ }^{77}$ a subject in the domain of chemistry, bore the same name as his most 'coarse. .horrid' Irish opponent, Rev. Samuel Haughton, who was also a mathematician, a geologist, and lately a medical doctor. Hooker reassured Darwin that it was one and the same man. ${ }^{78}$ Haughton's name is, at least in the narrower circle of professional scientists, more securely preserved through a number of current initiatives, ${ }^{79}$ but, like Galbraith, he has not been the subject of a full-length biography.

In the duo, Galbraith seems to have taken the lead at the beginning (the Angeli case, the manuals), but towards the end of their lives Haughton played more and more the role of elder brother. Haughton's wife and sons lived longer,

\footnotetext{
75 Haughton, 'The principle of least action in nature, illustrated by animal mechanics being three lectures delivered at the Royal Institution of Great Britain' (London, 1871). F. Richards was favourably reviewed by colleagues, for instance Trotter. See Haughton, 'Principles of Animal Mechanics', J. Anat. Physiol. C7 (2) (1873), 312-8.

76 Letter from Charles Darwin to J.D. Hooker (1862), Darwin Correspondence Online Project (available at: www.darwinproject.ac.uk/entry-3793/ (letter no. 3793), 12 October 2010). Part of Darwin's confusion might have arisen from hearing of James Haughton, who, like Darwin, was an anti-slave trade activist who had a son also called Samuel. See Haughton, Memoir of James Haughton by his son Samuel Haughton (Dublin, 1877).

77 Haughton, 'On the use of nicotine in tetanus and cases of poisoning by strychnine', Dublin Quarterly Journal of Medical Science 34 (1862), 172-86.

78 Letter from J.D. Hooker to Charles Darwin (1862), Darwin Correspondence Online Project (available at: www.darwinproject.ac.uk/entry-3802/ (letter no. 3802), 12 October 2010)

79 A series of 'Haughton Lectures' focuses directly on his animal mechanics work, for instance P.J. Prendergast and T.C. Lee, 'On a wing and a prayer: the biomechanics of the Rev. Samuel Haughton (1821-1897)', Journal of the Irish College of Physicians and Surgeons 28 (1) (1999), 18-43; P.J. Prendergast, 'May the force be with you' 14th Samuel Haughton Lecture, Irish Journal of Medical Science 177 (2008), 289-96.
} 
while Galbraith was widowed early, after only seventeen years of marriage, and two of his children, Sarah Jane and Richard, also died young (in 1869 and 1888; Elizabeth died in 1891). Galbraith was the object of sharper rejection by some of their peers, while Haughton was generally more successful in his undertakings. He failed, however, to make a scientist of Galbraith, but then Galbraith also failed to make a party man of Haughton. Galbraith's succinct diaries register their very frequent-for years, daily-interaction, and their rich professional, social and home life. One of Galbraith's grandchildren spent a decade gathering newspaper cuttings and other documents pertaining to his ancestor's public life, ${ }^{80}$ and trying to motivate Trinity College and Church of Ireland authorities to erect a public memorial for his ancestor. Although his efforts came to nothing, they have provided the basis for this paper and for further developments now in progress. Academia, like history, moves at its own pace.

Acknowledgements The author is very grateful to the staff at the Early Printed Books and the Old Manuscripts sections of the Library at Trinity College Dublin and to Patrick N. Wyse Jackson and Norman MacMillan for enjoyable discussions on the subjects. And to Rebecca Hayes, archivist of the Grand Masonic Lodge, Molesworth Street, who helped me to check the facts of the Galbraith controversy. I am also very grateful to Maggie Armstrong in the Publications Office of the Royal Irish Academy for her help with the editing of the manuscript.

80 TCD-JAG-MS 3856/1/48, Galbraith's grandchild, Leut Col. Edward D. Galbraith Woods, DSO, OBE, who served in India during World War II made serious efforts, during 1951 to 1962 , to secure public recognition for his grandfather, and was responsible for all the documentation in Trinity College's archives that has made this paper possible. No one of authority in Trinity College or in the Church of Ireland took up the subject, and thus no memorial plaque, bust or painting, published biography or student scholarship remains to commemorate his name. 